\title{
Effect of various high-pressure treatments on the properties of reduced-fat Cheddar cheese
}

\author{
M. Ozturk, ${ }^{*}$ S. Govindasamy-Lucey, $†$ J. J. Jaeggi, $†$ K. Houck, $†$ M. E. Johnson, $†$ and J. A. Lucey* ${ }^{1}$ \\ ${ }^{*}$ Department of Food Science, and \\ †Wisconsin Center for Dairy Research, University of Wisconsin-Madison, 1605 Linden Drive, Madison 53706
}

\begin{abstract}
A major problem with reduced-fat cheese is the difficulty in attaining the characteristic flavor and texture of typical full-fat versions. Some previous studies have suggested that high hydrostatic pressure (HHP) can accelerate the ripening of full-fat cheeses. Our objective was to investigate the effect of HHP on reduced-fat ( $\sim 7.3 \%$ fat) Cheddar cheese, with the goal of improving its flavor and texture. We used a central composite rotatable design with response surface methodology to study the effect of pressure and holding time on the rheological, physical, chemical, and microbial characteristics of reduced-fat Cheddar cheese. A 2-level factorial experimental design was chosen to study the effects of the independent variables (pressure and holding time). Pressures were varied from around 50 to 400 $\mathrm{MPa}$ and holding times ranged from 2.5 to $19.5 \mathrm{~min}$. High pressure was applied 1 wk after cheese manufacture, and analyses were performed at $2 \mathrm{wk}$, and 1, 3, and 6 mo. The insoluble calcium content as a percentage of total $\mathrm{Ca}$ in cheeses were not affected by pressure treatment. Pressure applications $\geq 225 \mathrm{MPa}$ resulted in softer cheese texture during ripening. Pressures $\geq 225$ $\mathrm{MPa}$ increased melt, and resulted in higher maximum loss tangent values at 2 wk. Pressure treatment had a greater effect on cheese microbial and textural properties than holding time. High-pressure-treated cheeses also had higher $\mathrm{pH}$ values than the control. We did not observe any significant difference in rates of proteolysis between treatments. In conclusion, holding times of around 5 min and pressures of $\geq 225 \mathrm{MPa}$ could potentially be used to improve the excessively firm texture of reduced-fat cheese.
\end{abstract}

Key words: high-pressure processing, reduced-fat cheese, insoluble calcium phosphate, cheese functionality

Received December 13, 2012.

Accepted August 6, 2013.

${ }^{1}$ Corresponding author: jlucey@cdr.wisc.edu

\section{INTRODUCTION}

Cheese flavor development is a complex and timeconsuming process that is not fully understood. Proteolysis is one of the most important steps in cheese ripening (McSweeney and Sousa, 2000; Sousa et al., 2001). Several methods have been developed to improve cheese flavor development, such as addition of adjunct cultures, using modified starters, increased storage temperatures, and the addition of exogenous enzymes (Law, 2001). Previous studies indicated that the application of high hydrostatic pressure (HHP) to cheese can have a positive effect on cheese ripening, probably as a result of increased starter lysis and the breakage, and only partial reforming, of bonds in the protein matrix (Yokohama et al., 1992; Messens et al., 1997). Yokohama et al. (1992) claimed that HHP treatment of young cheese at $50 \mathrm{MPa}$ for $72 \mathrm{~h}$ gave comparable proteolysis rates and flavor development to 6-mo-old conventionally aged Cheddar cheese. Later, O'Reilly et al. (2000) and Saldo et al. (2002) applied similar conditions (50 MPa for 72 h) to Cheddar and goat milk cheeses, respectively, but the increase in the proteolysis was not as significant as the rates suggested by Yokohama et al. (1992). An increase in the proteolysis rate of Camembert cheese (Reps et al., 1998) was observed upon the application of $50 \mathrm{MPa}$ for $4 \mathrm{~h}$. Nevertheless, HHP treatment did not have any significant influence on the proteolysis of Gouda cheese (Reps et al., 1998; Messens et al., 1999). Other authors have studied the use of higher pressures for shorter times. Saldo et al. (2003) treated goat milk cheese at $400 \mathrm{MPa}$ for $5 \mathrm{~min}$ and reported that HHPtreated cheese had twice the levels of total free amino acids compared with untreated cheese. However, this HHP treatment (400 MPa for 5 min) decreased lipolysis in this cheese, which was considered an unfavorable effect for goat cheese (Saldo et al., 2003).

Reducing the fat content of cheese significantly changes starter activity, starter lysis, flavor development, flavor release, and texture (Bryant et al., 1995; Carunchia Whetstine et al., 2006). High hydrostatic pressure treatment $(100-500 \mathrm{MPa})$ of half-fat $(\sim 15 \%)$ Cheddar cheese for $2 \mathrm{~h}$ resulted in softer cheese texture and increased meltability (Johnston et al., 2002). It was 
also reported that half-fat Cheddar cheese treated at $200 \mathrm{MPa}$ exhibited the closest textural properties to the full-fat control. On the other hand, the application of $400 \mathrm{MPa}$ for 5 min to reduced-fat Mozzarella cheese did not influence its rheological properties (Sheehan et al., 2005).

Conflicting results have emerged from the various HHP studies; one issue is the different process conditions used. We therefore wanted to explore a wide range of pressures and times to see if we could determine some suitable conditions to improve the quality of reduced-fat Cheddar cheese. We are not aware of any studies on the use of HHP to improve the properties of cheese around this fat level $(\sim 7 \%)$. The objective of this study was to determine the effect of pressure and holding time on the texture and characteristics of reduced-fat Cheddar cheese.

\section{MATERIALS AND METHODS}

\section{Cheese Manufacture}

A licensed Wisconsin cheesemaker manufactured 2 independent batches of reduced-fat, milled-curd Cheddar cheeses at the University of Wisconsin-Madison Dairy Plant over a period of 1 yr. Skim milk $(0.45 \pm$ $0.15 \%$ fat) was pasteurized at $73^{\circ} \mathrm{C}$ for $19 \mathrm{~s}$, cooled to $32.2^{\circ} \mathrm{C}$, and preacidified to $\mathrm{pH} 6.50$ with $25 \%$ citric acid solution. The milk was inoculated with a mesophilic mixed-strain starter culture consisting of Lactococcus lactis ssp. cremoris and Lactococcus lactis ssp. lactis (LL50; DSM Foods, JH Heerlen, the Netherlands), and starter adjunct Lactobacillus helveticus (LH-32; Chr. Hansen Inc., Milwaukee, WI) at the rate of 381 and 9.5 g per $1,672 \mathrm{~kg}$ of milk, respectively. Cheese milk was ripened at $33.3^{\circ} \mathrm{C}$ for $30 \mathrm{~min}$. Annatto (Cheese Color $2 \times$; Chr. Hansen Inc.) was added as colorant right after starter culture addition at the rate $105 \mathrm{~mL}$ per 1,672 $\mathrm{kg}$ of milk. Double-strength chymosin [Chy-Max Extra; 600 international milk clotting units (IMCU) $/ \mathrm{mL}$; Chr. Hansen Inc.] was added at the rate of $142 \mathrm{~g}$ per 1,672 $\mathrm{kg}$ of milk. The coagulum was cut with $1.9-\mathrm{cm}$ knives and the curd was given a 10-min healing time before cooking. The temperature of the curd-whey mixture was raised from approximately 32 to $34.5^{\circ} \mathrm{C}$ over 15 min. The curd was held at $34.5^{\circ} \mathrm{C}$ for 15 min before draining the whey. Curd slabs were cheddared, stacked 2 high, and milled at a $\mathrm{pH}$ of approximately 5.9. The curd was rinsed with cold water $(\sim 20 \mathrm{~L})$ for $15 \mathrm{~s}$ after milling. The curd was salted at the rate of $6.3 \mathrm{~kg}$ per $1,672 \mathrm{~kg}$ of milk and was packed in 11-kg Wilson-style hoops $(35 \times 28 \times 13 \mathrm{~cm})$ and pressed at ambient temperature until the $\mathrm{pH}$ reached about $5.4(\sim 2 \mathrm{~h})$; then, cheese blocks were vacuum packaged and aged at $7^{\circ} \mathrm{C}$.

\section{HHP Treatment}

Cheeses were HHP treated 1 wk after manufacture. The conditions used are given in Table 1. The commercial high-pressure unit (Avure Ultra 215 L; Avure Technologies Inc., Kent, WA) has a volume of $215 \mathrm{~L}$ and can process up to $150 \mathrm{~kg}$ of product per cycle, depending on product size and packaging. The HHP unit can reach pressures of up to $600 \mathrm{MPa}$, and a complete compression/decompression cycle takes 4 to $5 \mathrm{~min}$, excluding holding time. The machine reached $48 \mathrm{MPa}$ in around $6 \mathrm{~s}$ and approximately $400 \mathrm{MPa}$ in around $100 \mathrm{~s}$. Water was used as the pressure-transfer medium. The water temperature of the holding tank of the HHP unit was between 7 to $11^{\circ} \mathrm{C}$. An untreated cheese block was used as a control for each trial.

\section{Sampling and Composition Analyses}

In several cheese blocks, we observed acid spot defect occurring before the pressure treatment (possibly reflecting localized regions where citric acid was added). After realizing that the data we obtained from these regions were not representative of the remainder of the cheese block, we decided to avoid sampling from these regions. The data received from these regions were excluded in our calculations/results.

The cheese milk was analyzed for fat (Mojonnier method; AOAC International, 2000), protein (total percentage $\mathrm{N} \times 6.38$, Kjeldahl method; AOAC International, 2000), casein (AOAC International, 2000), lactose (AOAC International, 2000), TS (Green and Park, 1980), total Ca (Park, 2000), and insoluble calcium (INSOL Ca) by the acid-base titration method (Lucey et al., 1993; Hassan et al., 2004). Unacidified milk was used to generate rennet whey (Lucey et al., 1993), which was analyzed for total soluble Ca (Park, 2000). The cheeses were analyzed at 1 mo for moisture (Marshall, 1992), fat (AOAC International, 2000), $\mathrm{pH}$ using a pH electrode (Sam Gray gold electrode; Nelson-Jameson Inc., Marshfield, WI; Marshall, 1992), protein by the Kjeldahl method (AOAC International, 2000), and salt by the chloride electrode method (model 926; Corning Glass Works, Medfield, MA; Johnson and Olson, 1985); lactose/galactose and lactic acid contents were analyzed enzymatically (Boehringer Mannheim, 1997; Severn et al., 1986) and total Ca content was determined (Park, 2000). Proteolysis was monitored with water-soluble $\mathrm{N}$ and $12 \%$ TCA-soluble N (Kuchroo and Fox, 1982). The INSOL Ca contents in cheeses were measured at time points of 2 wk and 1, 3, and 6 mo. Acid-base titrations of the cheeses were performed as described by Lucey et al. (1993). The INSOL Ca contents in cheeses were calcu- 
Table 1. Values of independent variables of each experiment in coded and actual values for the central composite experimental design

\begin{tabular}{|c|c|c|c|c|}
\hline \multirow[b]{2}{*}{ Sample no. } & \multicolumn{2}{|c|}{ Coded value $^{1}$} & \multicolumn{2}{|c|}{ Actual value } \\
\hline & Time & Pressure & Time (min) & Pressure (MPa) \\
\hline 1 & -1 & 1 & 5 & 350 \\
\hline 2 & 1 & -1 & 17 & 100 \\
\hline 3 & 1 & 1 & 17 & 350 \\
\hline 4 & 0 & $+\alpha$ & 11 & 402 \\
\hline 5 & $+\alpha$ & 0 & 19.5 & 225 \\
\hline 6 & -1 & -1 & 5 & 100 \\
\hline 7 & 0 & 0 & 11 & 225 \\
\hline 8 & 0 & $-\alpha$ & 11 & 48 \\
\hline 9 & $-\alpha$ & 0 & 2.5 & 225 \\
\hline 10 & 0 & 0 & 11 & 225 \\
\hline
\end{tabular}

lated by the acid-base titration method as described by Hassan et al. (2004).

\section{Rheological Measurements}

Dynamic small-amplitude oscillatory rheology was used to measure the rheological properties of the reduced-fat Cheddar cheese. A Paar Physica UDS 200 controlled-stress rheometer (Anton Paar, Ashland, VA) with 50-mm serrated parallel plate geometry was used as described by Lee et al. (2005). Cheese samples that were $50 \mathrm{~mm}$ in diameter and $3 \mathrm{~mm}$ in thickness were prepared, and heated from 5 to $85^{\circ} \mathrm{C}$ at a heating rate of $3^{\circ} \mathrm{C} / \mathrm{min}$. A frequency of $0.08 \mathrm{~Hz}$ and a strain of $0.5 \%$ were applied to measure the storage modulus $\left(\mathbf{G}^{\prime}\right)$, loss modulus $\left(\mathbf{G}^{\prime \prime}\right)$, and loss tangent $(\mathbf{L T})$, which is the ratio between the viscous properties and the elastic properties of the material $\left(\mathrm{LT}=\mathrm{G}^{\prime} / \mathrm{G}^{\prime \prime}\right)$. The maximum loss tangent (LTmax) value observed during heating was also recorded.

\section{Microbiological Analysis}

The numbers of lactococci starters were measured by incubation anaerobically on de Man, Rogosa, and Sharpe (MRS) agar at $32^{\circ} \mathrm{C}$ for $48 \mathrm{~h}$ (Wehr and Franks, 2004) and nonstarter lactobacilli were counted on Rogosa SL medium grown anaerobically at $32^{\circ} \mathrm{C}$ for 48 to $72 \mathrm{~h}$ (Broadbent et al., 2003). The plates were incubated longer than usual because pinpoint colonies were observed, which were hard to read. This might have been due to the processing conditions used, causing stressed cells and affecting their growth.

\section{Melt Profile Analysis}

The UW-MeltProfiler (University of Wisconsin, Madison) was used, as described by Muthukumarappan et al. (1999), to evaluate melt and flow characteristics of cheese samples. Disk-shaped cheese samples (7-mm thick and $30 \mathrm{~mm}$ in diameter) were prepared and stored at $6^{\circ} \mathrm{C}$ at least $3 \mathrm{~h}$ before testing. A thermocouple was inserted into the center of the cheese disk held between 2 lubricated aluminum plates and placed into an oven at $72^{\circ} \mathrm{C}$ (750F Forced Air Oven; Fisher Scientific, Pittsburgh, PA). Changes in cheese height and cheese temperature were measured for $15 \mathrm{~min}$. Degree of flow (DOF) was calculated as the change in height when the cheese temperature reached $60^{\circ} \mathrm{C}$ compared with the cheese height at the beginning of the test. Cheese samples were analyzed at $2 \mathrm{wk}$ and 1,3 , and 6 mo of ripening.

\section{Texture Profile Analysis and Uniaxial Compression}

Texture profile analysis (TPA) and uniaxial compression were measured using a TA.XT2 Texture Analyzer (Texture Technologies Corp., Scarsdale, NY). Samples were prepared with a cork borer with a diameter of 16 $\mathrm{mm}$ and a height of $17.5 \mathrm{~mm}$. For the TPA test, cheeses were compressed by $20 \%$ using a $50-\mathrm{mm}$ aluminum cylinder test probe with a cross-head speed of $0.8 \mathrm{~mm} / \mathrm{s}$. For uniaxial compression, cheeses were compressed by $80 \%$ with the same test probe and cross-head speed as for the TPA test. All tests were performed at $5^{\circ} \mathrm{C}$ and replicated at least 5 times.

\section{Fluorescence Microscopy}

Micrographs of the reduced-fat Cheddar cheeses were obtained using a similar procedure as described by Sutheerawattananonda et al. (1997). Cheese samples were cut from the center of each cheese block, and sectioned using a sharp razor blade. Cheese sections were stained with $0.1 \%$ (wt/vol) Nile blue A (Sigma-Aldrich, St. Louis, MO) or acridine orange (Sigma-Aldrich) for 1 
min and rinsed with milli-Q water (Millipore Corp., Billerica, MA). The stained sections were held at $4^{\circ} \mathrm{C}$ and analyzed within a day using a fluorescence microscope (Axioskop 2 plus; Carl Zeiss AG, Eching, Germany) fitted with a $40 \times$ objective (Achroplan $40 \times / 0.75$; Carl Zeiss).

\section{Experimental Design and Statistical Analyses}

A central composite rotatable design (Mullen and Ennis, 1979) and response surface methodology (Montgomery, 2001) were used to investigate the effects of pressure and holding time on the rheological, physical, and chemical characteristics of reduced-fat Cheddar cheese. A 2-level factorial experimental design was chosen to study the effects of the independent variables (pressure and holding time) with 2 star points $(\alpha=$ 1.414) and 2 replicates of the center point (Table 1 ). Experimental conditions were repeated with 2 independent trials. The coded variables were related to the real units by Equations 1 and 2:

$$
\begin{aligned}
& \text { Coded pressure }=\frac{(\text { pressure }-225)}{125} ; \\
& \text { Coded time }=\frac{(\text { holding time }-11)}{6} .
\end{aligned}
$$

Multiple (stepwise) regression and response surface methodology were used to analyze the results (Statgraphics version 5.1 plus; Manugistics Inc., Rockville, $\mathrm{MD})$. Response variables were estimated by using second-order (polynomial) models, which provide a good description of the geometric slope of response surfaces. Stepwise regression was used to eliminate insignificant factors $(F$-value $<4)$ using backward selection, which begins with all of the variables in a model and removes them one at a time to simplify the model (Montgomery, 2001). The Tukey-Kramer test was used to compare means, and differences between means were considered significant at $P<0.05$. Pearson correlation coefficients were estimated between various responses (i.e., INSOL Ca, $12 \%$ TCA-soluble N, water-soluble N, TPA hardness, rheological parameters, and DOF).

\section{RESULTS AND DISCUSSION}

\section{Composition and Microbiology}

The composition of the cheese was $52.2 \pm 0.9 \%$ moisture, $7.3 \pm 0.2 \%$ fat, $32.8 \pm 1 \%$ protein, and $1.84 \pm$ $0.24 \%$ salt. Considerable variation existed among the $\mathrm{pH}$ values (5.01-5.28) and residual lactose contents $(0.22-0.6 \%)$ observed in the experimental treatments a

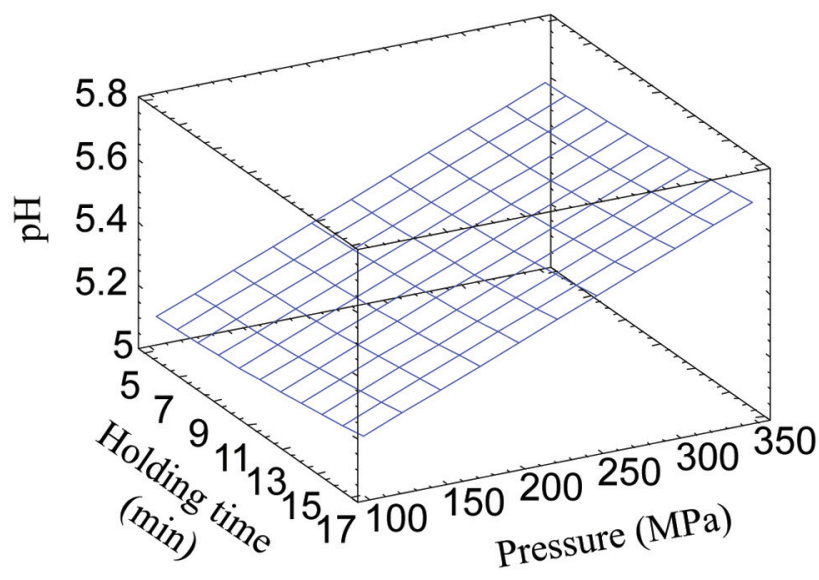

b
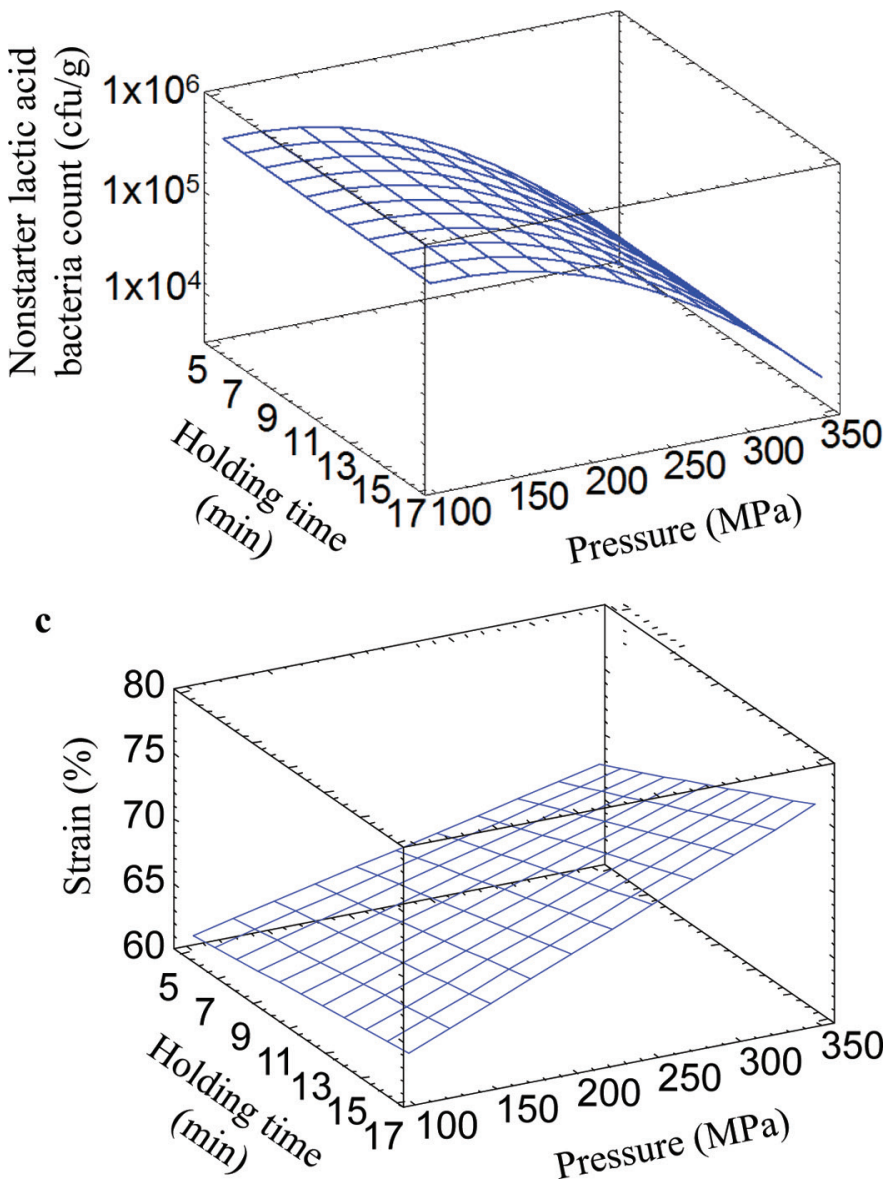

Figure 1. Response-surface plots for the effect of pressure and holding times on $\mathrm{pH}$ values at $1 \mathrm{mo}$ (a), nonstarter lactic acid bacteria numbers $(\mathrm{cfu} / \mathrm{g}$ ) at $1 \mathrm{mo}$ (b), and percentage fracture strain at $2 \mathrm{wk}$ (c) of age. Color version available in the online PDF.

at 1 mo. An increase in pressure resulted in higher $\mathrm{pH}$ values (Figure 1a), and residual lactose levels (Table 2 ), and lower levels of lactic acid (results not shown). Linear effect of pressure was the most significant experimental variable for $\mathrm{pH}$ and residual lactose; pres- 
Table 2. Second-order polynomial models describing $\mathrm{pH}$ at $1 \mathrm{mo}$, residual lactose content as a percentage of total weight at $1 \mathrm{mo}$, starter bacteria numbers at $1 \mathrm{mo}$ of age, nonstarter lactic acid bacteria (NSLAB) numbers at $1 \mathrm{mo}$, hardness at $2 \mathrm{wk}$, and strain to fracture at $2 \mathrm{wk}^{1}$

\begin{tabular}{|c|c|c|c|c|}
\hline $\begin{array}{l}\text { Dependent } \\
\text { variable }\end{array}$ & $\begin{array}{l}\text { Independent } \\
\text { variable }\end{array}$ & Coefficient & $\begin{array}{c}\mathrm{R}^{2} \\
\text { (adjusted) }^{2}\end{array}$ & $P$-value \\
\hline $\mathrm{pH}$ & $\begin{array}{l}\text { Constant } \\
\text { Pressure* }^{*} \\
\text { Time }^{2}\end{array}$ & $\begin{array}{l}4.9 \\
0.002 \\
0.0003\end{array}$ & 0.9 & $<0.05$ \\
\hline Lactose content & $\begin{array}{l}\text { Constant } \\
\text { Pressure }\end{array}$ & $\begin{array}{l}0.007 \\
0.004\end{array}$ & 0.67 & $<0.05$ \\
\hline Starter no. (log) & $\begin{array}{l}\text { Constant } \\
\text { Pressure*** }\end{array}$ & $\begin{aligned} & 8.39 \\
- & 0.0078\end{aligned}$ & 0.93 & $<0.0001$ \\
\hline NSLAB no. (log) & $\begin{array}{l}\text { Constant } \\
\text { Pressure } \\
\text { Pressure }\end{array}$ & $\begin{aligned} & 5.18 \\
& 0.0067 \\
- & 3 \mathrm{E}-05\end{aligned}$ & 0.90 & $<0.05$ \\
\hline Hardness (N) & $\begin{array}{l}\text { Constant } \\
\text { Pressure** }\end{array}$ & $\begin{array}{c}14.23 \\
-0.013\end{array}$ & 0.79 & $<0.001$ \\
\hline Strain to fracture & $\begin{array}{l}\text { Constant } \\
\text { Time } \times \text { pressure** } \\
\text { Pressure }\end{array}$ & $\begin{array}{c}58.42 \\
0.002 \\
0.018\end{array}$ & 0.94 & $<0.05$ \\
\hline
\end{tabular}

${ }^{1}$ Only prediction models with $\mathrm{R}^{2}$ (adjusted) $>0.5$ are shown.

${ }^{2}$ Coefficient of determination values were adjusted for the degrees of freedom

$P<0.05 ;{ }^{*} P<0.005 ;{ }^{* *} P<0.001 ;{ }^{* * *} P<0.0001$.

sure positively affected both $\mathrm{pH}$ and residual lactose values (Table 2). Previous studies also indicated that HHP application to cheese resulted in higher $\mathrm{pH}$ values in Cheddar (Rynne et al., 2008), Gouda (Messens et al., 1999; Messens et al., 2000), Mozzarella (Johnston and Darcy, 2000; Sheehan et al., 2005), goat milk (Saldo et al., 2000; Saldo et al., 2003), and ewe milk cheese (Juan et al., 2007b). Two possible mechanisms could explain the high $\mathrm{pH}$ values in HHP-treated cheeses; HHP could dissociate ionizable groups of protein and thus alter pH (Rynne et al., 2008) and (or) inactivate the starter bacteria or their glycolytic enzymes before complete fermentation of lactose (Malone et al., 2003; Rynne et al., 2008). Residual lactose level was higher for the application of $225 \mathrm{MPa}$ for $2.5 \mathrm{~min}(0.42 \pm$ $0.04 \%)$ compared with the control $(0.24 \pm 0.05 \%)$ even for this sample that did not exhibit significant microbial reduction (Figure 2) due to HHP. This indicates a possible impairment in the glycolytic pathway. Similar to our observation, Casal and Gomez (1999) reported that HHP affected the acidifying activity of lactococci and lactobacilli to a greater extent than their cell viability. However, we have limited information about the biological and enzymatic activity of the viable bacteria in our experimental cheese samples.

In our study, viable starter culture numbers decreased with HHP (Table 2). A highly significant $\left(\mathrm{R}^{2}=0.93\right.$ ) prediction model was obtained for starter culture numbers at 1 mo of ripening. Pressure was the significant term in this model, and pressure negatively affected starter bacteria numbers. Holding time seemed to have only very slight effect on bacterial reduction, which was in agreement with the results of Wick et al. (2004). At 2 wk of ripening, the use of pressures $\leq 225 \mathrm{MPa}$ did not exhibit significant $(P>0.05)$ reduction in starter culture numbers compared with control cheese (Figure $2 a$ ). Previous studies reported that pressures $\geq 200 \mathrm{MPa}$ were required to significantly decrease the viable lactic acid starter culture numbers (Casal and Gomez., 1999; O'Reilly et al., 2002b; Wick et al., 2004; Moschopoulou et al., 2010). The mechanisms by which HHP affects microorganisms is not fully understood, but cellular membrane damage seems to play a key role in their inactivation (Malone et al., 2002; Black et al., 2011). Intracellular and cell envelope damage was visible in transmission electron microscopy images of Lactococcus lactis strains treated by HHP (Malone et al., 2002). Martínez-Rodríguez et al. (2012) reported that regardless of processing time, a minimum pressure existed that had to be overcome for microbial inactivation. Application of 225 and $350 \mathrm{MPa}$ for $\geq 5$ min could have been enough to damage starter bacteria cells, and possibly these cells were no longer viable at 1 mo. Application of $402 \mathrm{MPa}$ for $11 \mathrm{~min}$ resulted in an approximately 2-log reduction in the numbers of starter bacteria (Figure 2a). It was reported that pressures of approximately $400 \mathrm{MPa}$ resulted in a 1.5- to 3.5-log reduction, depending on the cheese type and bacterial strain (Casal and Gomez, 1999; Saldo et al., 2000; O'Reilly et al., 2002b; Juan et al., 2007b; Rynne et al., 2008; Moschopoulou et al., 2010). Several studies have reported that an initial decrease in starter culture numbers immediately after HHP could be partially reversed (become viable again) during subsequent ripening (Wick et al., 2004; 

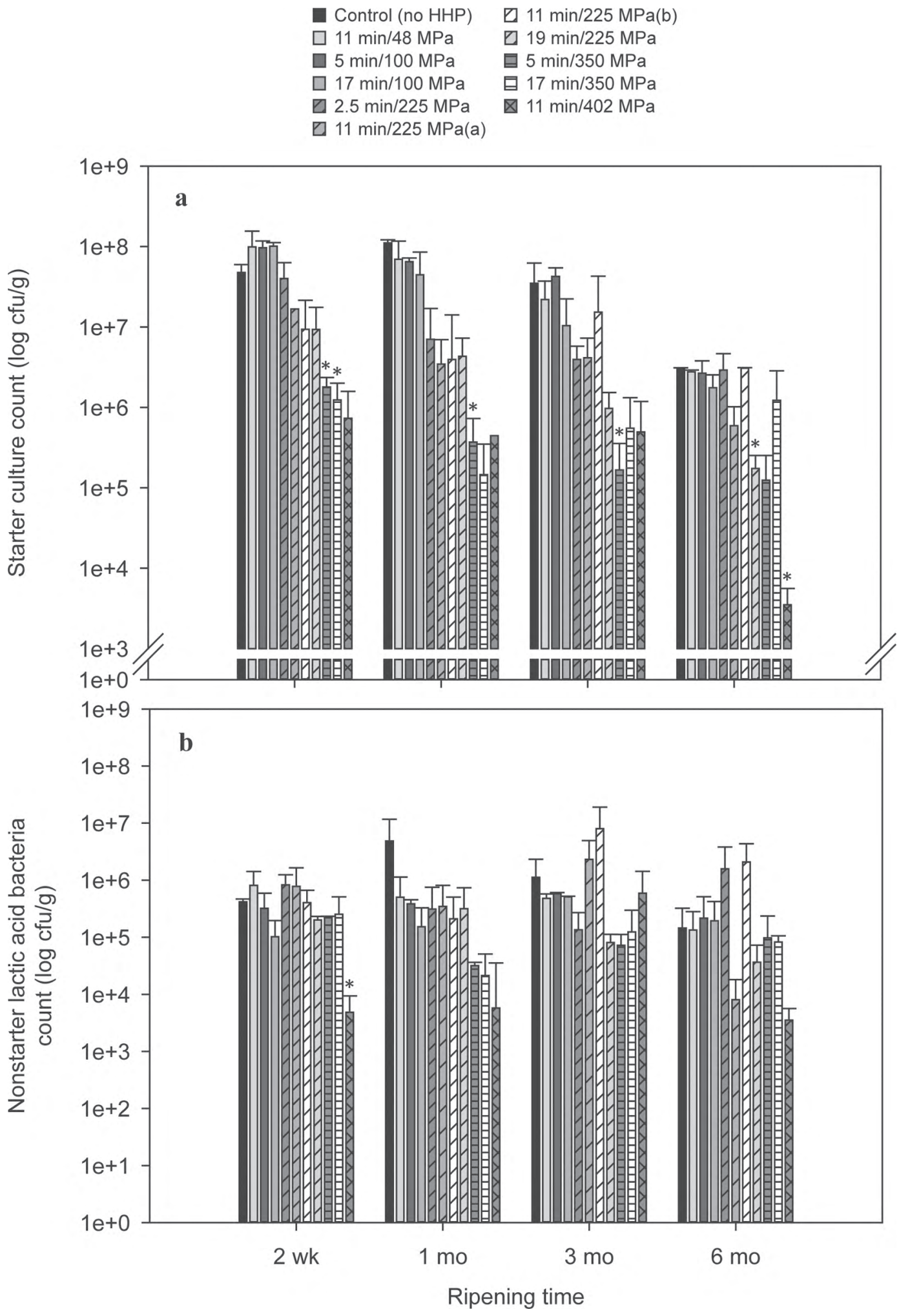

Figure 2. Starter culture (a) and nonstarter lactic acid bacteria (b) numbers of reduced-fat Cheddar cheeses for control, or cheeses treated for $11 \mathrm{~min}$ at $48 \mathrm{MPa}, 5 \mathrm{~min}$ at $100 \mathrm{MPa}, 17 \mathrm{~min}$ at $100 \mathrm{MPa}, 2.5$ min at $225 \mathrm{MPa}, 11 \mathrm{~min}$ at $225 \mathrm{MPa}(\mathrm{a}), 11 \mathrm{~min}$ at $225 \mathrm{MPa}(\mathrm{b}), 19 \mathrm{~min}$ at $225 \mathrm{MPa}, 5 \mathrm{~min}$ at $350 \mathrm{MPa}, 17 \mathrm{~min}$ at $350 \mathrm{MPa}$, or $11 \mathrm{~min}$ at $402 \mathrm{MPa}$ at 2 wk and 1, 3, and 6 mo of ripening at $7^{\circ} \mathrm{C}$. ${ }^{*}$ Significantly different from control $(P<0.05)$ at that indicated ripening time point. Values are means of 2 replicates and error bars represent SD. HHP $=$ high hydrostatic pressure. 

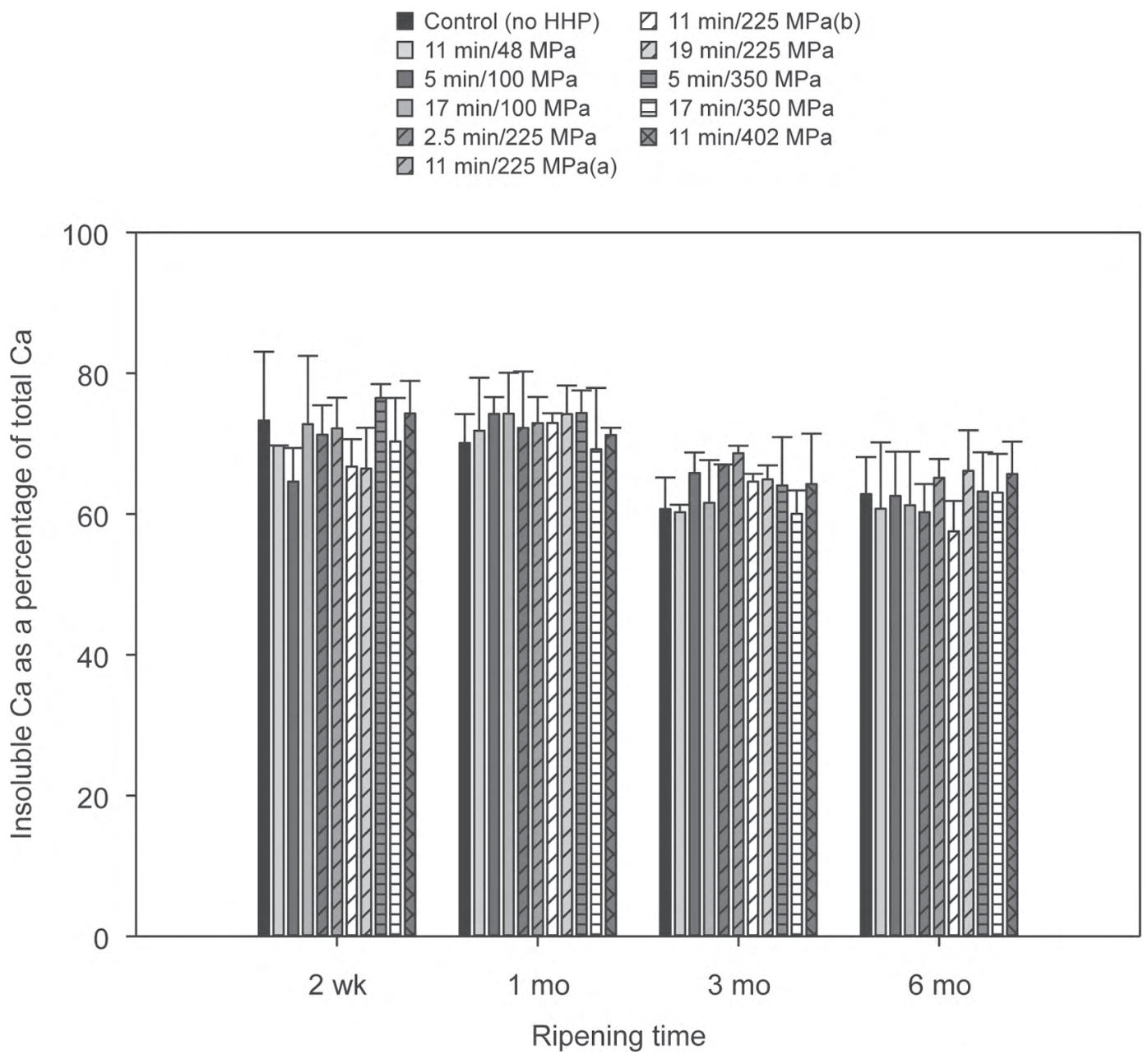

Figure 3. Insoluble calcium, expressed as a percentage of total calcium for reduced-fat Cheddar cheeses for control, or cheeses treated for 11 min at $48 \mathrm{MPa}, 5$ min at $100 \mathrm{MPa}, 17$ min at $100 \mathrm{MPa}, 2.5$ min at $225 \mathrm{MPa}, 11$ min at $225 \mathrm{MPa}(\mathrm{a}), 11 \mathrm{~min}$ at $225 \mathrm{MPa}(\mathrm{b}), 19 \mathrm{~min}$ at $225 \mathrm{MPa}$, $5 \mathrm{~min}$ at $350 \mathrm{MPa}, 17 \mathrm{~min}$ at $350 \mathrm{MPa}$, or $11 \mathrm{~min}$ at $402 \mathrm{MPa}$ at $2 \mathrm{wk}$ and 1 , 3, and 6 mo of ripening at $7^{\circ} \mathrm{C}$. Values are means of 2 replicates and error bars represent SD. HHP = high hydrostatic pressure.

Moschopoulou et al., 2010; Martínez-Rodríguez et al., 2012). In our study, we did not observe any significant $(P>0.05)$ increase in starter culture numbers in HHPtreated cheeses during ripening (Figure 2a).

Application of HHP significantly affected the nonstarter lactic acid bacteria (NSLAB; including nonstarter lactobacilli added as an adjunct) numbers at 1 mo of ripening (Figure 1b; Table 2). The prediction model had a coefficient of determination value of 0.90. Pressure had a linear (positive) effect as well as quadratic (negative) effect on NSLAB numbers. The NSLAB appeared to be more resistant to HHP compared with the starter lactococci strains. Casal and Gomez (1999) reported a similar trend for the pressure resistance for lactobacilli. The viability of lactobacilli species inoculated in $10 \%$ skim milk was not affected by the application of pressures between 100 and $350 \mathrm{MPa}$.
For pressures $\leq 225 \mathrm{MPa}$ applied to cheeses, NSLAB numbers did not show a significant $(P>0.05)$ increase from 2 wk to 1 mo, whereas NSLAB numbers increased $1 \log$ for the control cheese $(P<0.05$; Figure $2 \mathrm{~b})$. This result indicates that pressures of 50 to $225 \mathrm{MPa}$ initially slowed the development of NSLAB up to 1 mo of ripening. Intermediate pressure treatments (e.g., 350 $\mathrm{MPa}$ for 5 or $17 \mathrm{~min}$ ) and control cheese exhibited similar NSLAB numbers at 2 wk, but at 1 mo of ripening NSLAB numbers were approximately 2-log lower for these samples compared with the control. Both starter and NSLAB numbers exhibited a decrease from 2 wk to 1 mo of ripening with $350 \mathrm{MPa}$ applications, indicating that $350 \mathrm{MPa}$ did not cause immediate death of all pressure-sensitive bacteria in cheese, but it created stressed/damaged cells that were unable to recover during ripening. 


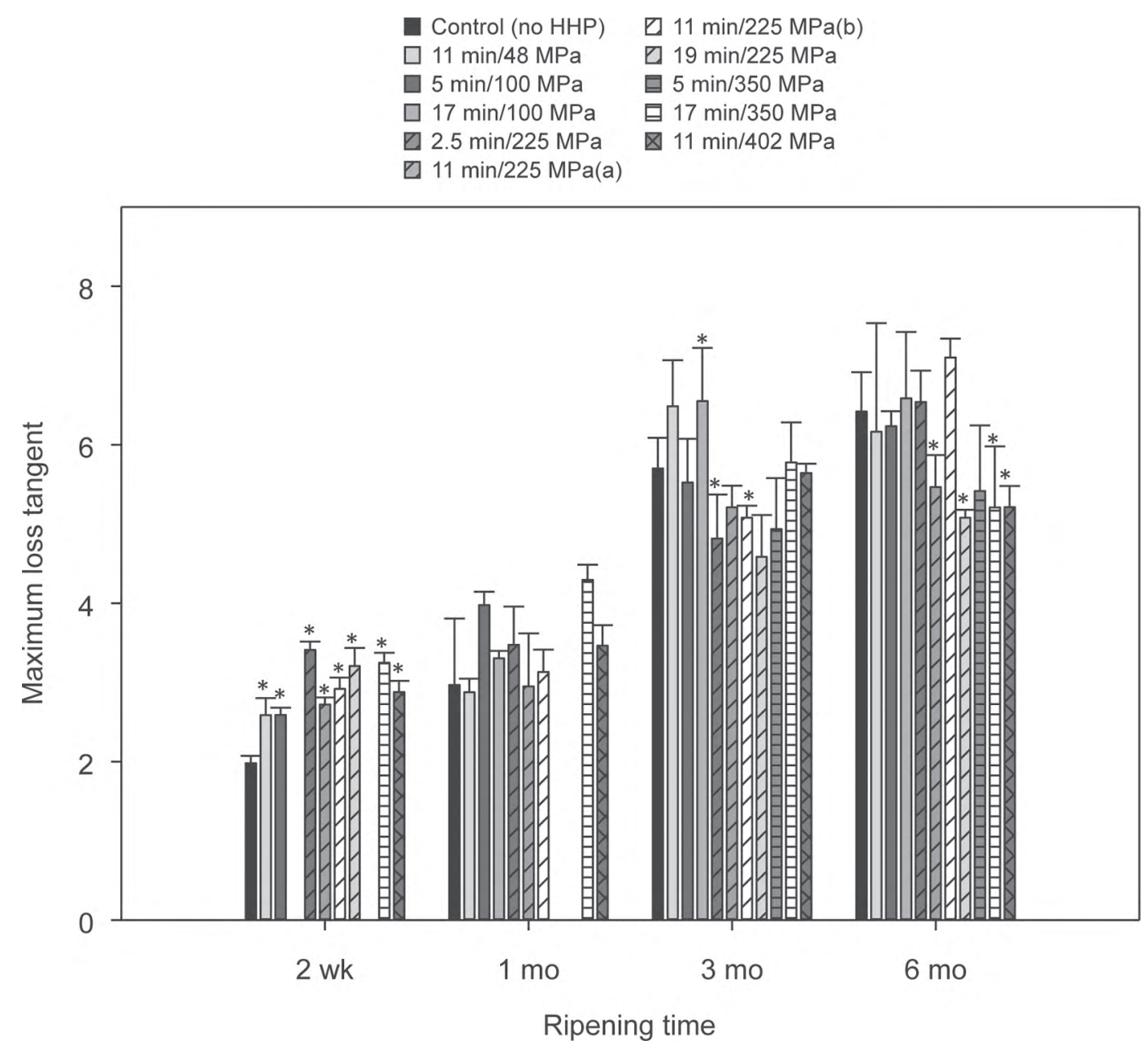

Figure 4. Maximum loss tangent values for reduced-fat Cheddar cheeses from the small-amplitude oscillatory rheology for control, or cheeses treated for $11 \mathrm{~min}$ at $48 \mathrm{MPa}, 5 \mathrm{~min}$ at $100 \mathrm{MPa}, 17 \mathrm{~min}$ at $100 \mathrm{MPa}, 2.5 \mathrm{~min}$ at $225 \mathrm{MPa}, 11 \mathrm{~min}$ at $225 \mathrm{MPa}$ (a), $11 \mathrm{~min}$ at $225 \mathrm{MPa}(\mathrm{b}), 19$ min at $225 \mathrm{MPa}, 5 \mathrm{~min}$ at $350 \mathrm{MPa}, 17 \mathrm{~min} 350$ at $\mathrm{MPa}$, or $11 \mathrm{~min}$ at $402 \mathrm{MPa}$ at 2 wk and 1, 3, and 6 mo of ripening at $7^{\circ} \mathrm{C}$. Some samples are not shown because we observed acid spots in these cheeses. ${ }^{*}$ Significantly different from control $(P<0.05)$ at that indicated ripening time point. Values are means of 2 replicates and error bars represent SD. HHP $=$ high hydrostatic pressure.

\section{Acid-Base Buffering Curves}

The INSOL Ca phosphate content plays a key role in the functional properties of cheese, such as hardness and meltability (Hassan et al., 2004). We did not observe any significant $(P>0.05)$ difference in INSOL Ca levels between HHP-treated cheeses and the control cheese during ripening (Figure 3). A slight decrease was observed in the INSOL Ca levels in cheeses with ripening, as was expected. The INSOL Ca content of cheese is reduced in low-pH cheeses (Lee et al., 2005). High hydrostatic pressure application resulted in cheeses exhibiting higher $\mathrm{pH}$ values, but we did not observe a parallel increase in the INSOL Ca levels for HHP-treated cheeses. Messens et al. (1998) investigated the serum phase of high-pressure-treated brined Gouda cheese. They reported that pressure treatment of $300 \mathrm{MPa}$ for $4.5 \mathrm{~min}$ did not influence the level of soluble Ca in cheese serum. Several studies investigated the state of $\mathrm{Ca}$ in HHP treated milk by analyzing the supernatant obtained by ultracentrifugation. DesobryBanon et al. (1994) reported that the application of HHP to milk resulted in a slight decrease in INSOL $\mathrm{Ca}$ up to $200 \mathrm{MPa}$, but a further increase in pressure resulted in milk with similar INSOL Ca levels to the control. Schrader et al. (1997) observed a reversible (with $72 \mathrm{~h}$ of storage) solubilization of INSOL Ca with the application of $400 \mathrm{MPa}$ for $5 \mathrm{~min}$. On the other hand, Law et al. (1998) did not observe any change in the state of $\mathrm{Ca}$ in goat milk with the application of pressures in the range 300 to $500 \mathrm{MPa}$. They suggested that pressure application solubilized INSOL Ca and pressure release shifted the calcium equilibrium back toward the INSOL phase. 

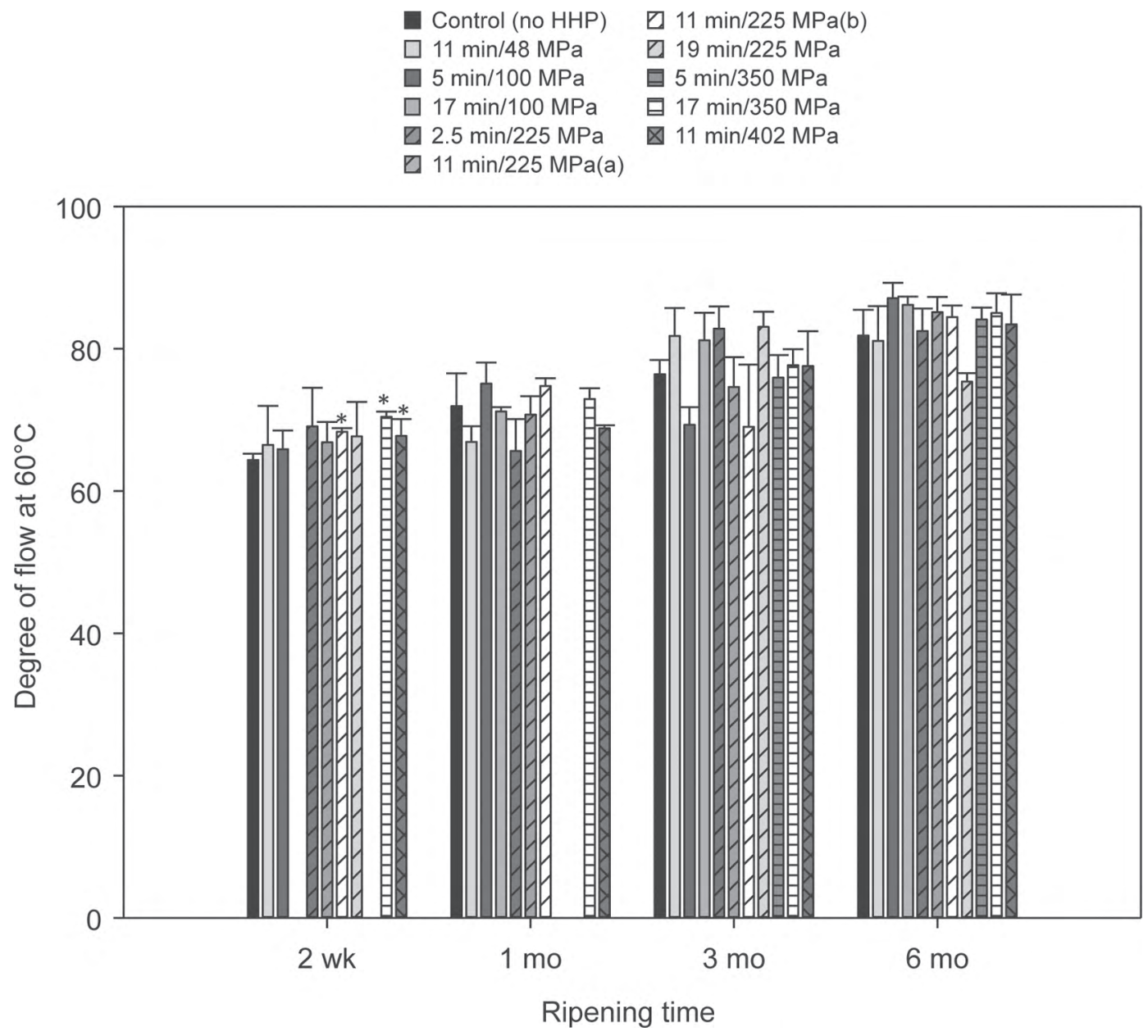

Figure 5. Degree of flow at $60^{\circ} \mathrm{C}$ [changes in cheese height as a percentage of the original height from the UW - MeltProfiler (University of Wisconsin, Madison)] for reduced-fat Cheddar cheeses for control, or cheeses treated for $11 \mathrm{~min}$ at $48 \mathrm{MPa}, 5 \mathrm{~min}$ at $100 \mathrm{MPa}, 17 \mathrm{~min}$ at $100 \mathrm{MPa}, 2.5 \mathrm{~min}$ at $225 \mathrm{MPa}, 11 \mathrm{~min}$ at $225 \mathrm{MPa}(\mathrm{a}), 11 \mathrm{~min}$ at $225 \mathrm{MPa}(\mathrm{b}), 19 \mathrm{~min}$ at $225 \mathrm{MPa}, 5 \mathrm{~min}$ at $350 \mathrm{MPa}, 17 \mathrm{~min}$ at $350 \mathrm{MPa}$, or 11 min at $402 \mathrm{MPa}$, at $2 \mathrm{wk}, 1,3$, and $6 \mathrm{mo}$ of ripening at $7^{\circ} \mathrm{C}$. Some samples are not shown because we observed acid spots in these cheeses. *Significantly different from control $(P<0.05)$ at that indicated ripening time point. Values are means of 2 replicates and error bars represent $\mathrm{SD}$. HHP $=$ high hydrostatic pressure.

\section{Rheological Properties and Meltability}

The LTmax values for all cheeses increased during ripening (Figure 4). The LTmax values of cheeses are used as an index of meltability. At 2 wk of ripening, the HHP applied cheeses exhibited higher LTmax values than the control (Figure 4). The DOF values of cheeses are shown in Figure 5. All cheeses exhibited an increase in the DOF (melt) during ripening. At 2 wk of ripening, several HHP treatments exhibited significantly $(P<0.05)$ higher DOF than the control. At 1 mo of ripening, all HHP-treated and control cheeses exhibited similar DOF and LTmax values. Various types of casein interactions in the cheese network determine its rheological and melting properties (Lucey et al., 2003). We did not observe any significant $(P>$ 0.05) change in the state of Ca between HHP-treated cheeses and the control (Figure 3), indicating that other changes in casein-casein interactions contributed to the observed differences in rheological and melt properties shortly after HHP application. Messens et al. (2000) reported that the application of HHP to cheese created a more fluid-like structure immediately after pressure processing, and increased the LTmax values in Gouda cheese. In agreement with our study, differences in the rheological properties between HHPtreated Gouda cheese and the control became smaller during ripening (42 d; Messens et al., 2000). Messens et al. (2000) indicated that HHP decreased hydrophobic interactions between caseins immediately after pressure processing. O'Reilly et al. (2002a) and Johnston and Darcy (2000) indicated that HHP-induced protein hydration was responsible for the increase in melt flow and LTmax after HHP treatment. By 1 mo of 

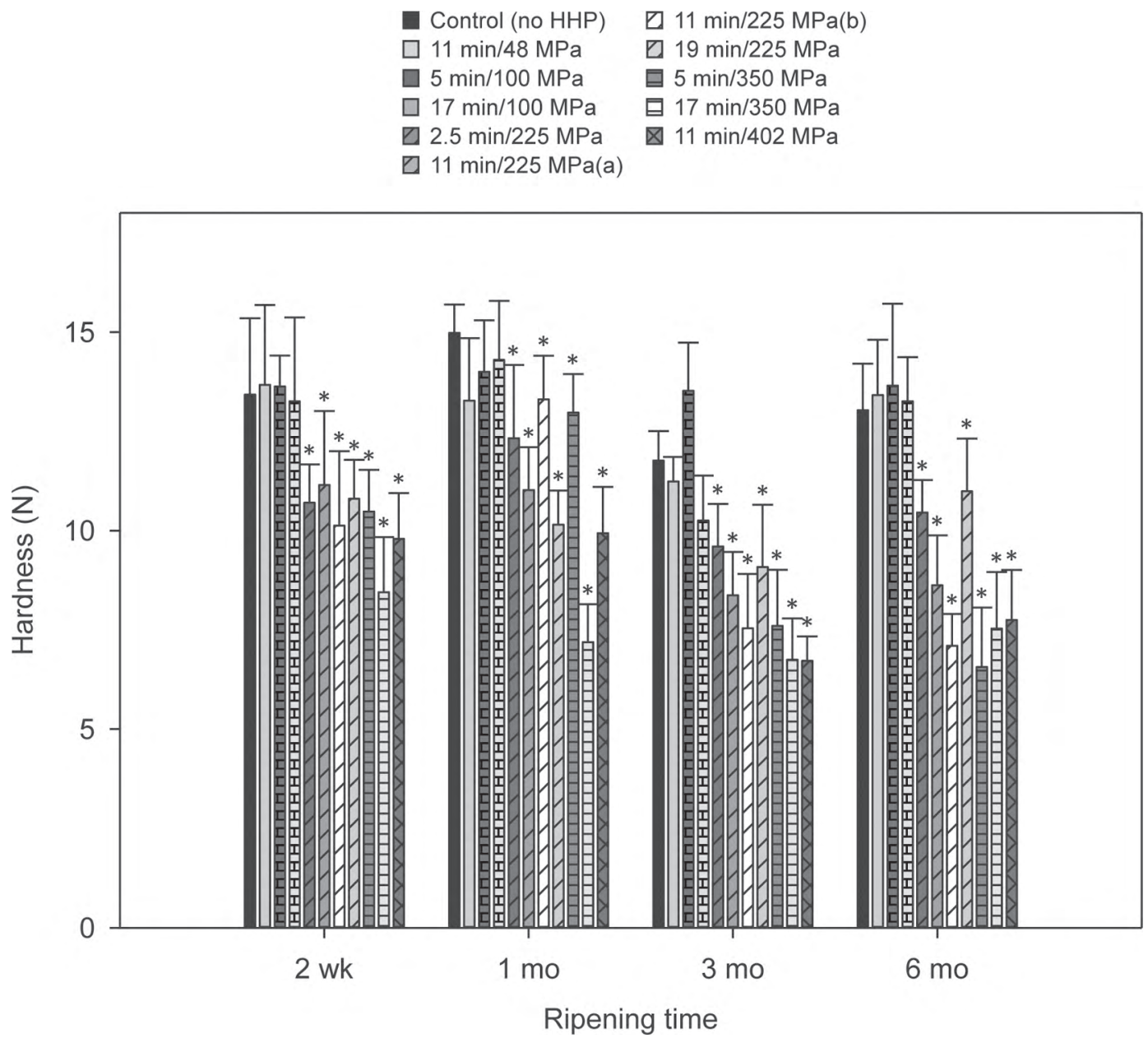

Figure 6. Hardness (N) from texture profile analysis testing (20\% compression of cheese cylinders to original height) for reduced-fat Cheddar cheeses for control, or cheeses treated for $11 \mathrm{~min}$ at $48 \mathrm{MPa}, 5$ min at $100 \mathrm{MPa}, 17$ min at $100 \mathrm{MPa}, 2.5 \mathrm{~min}$ at $225 \mathrm{MPa}, 11 \mathrm{~min}$ at $225 \mathrm{MPa}(\mathrm{a})$, 11 min at $225 \mathrm{MPa}(\mathrm{b}), 19 \mathrm{~min}$ at $225 \mathrm{MPa}, 5$ min at $350 \mathrm{MPa}, 17$ min at $350 \mathrm{MPa}$, or 11 min at $402 \mathrm{MPa}$ at 2 wk and 1,3 , and 6 mo of ripening at $7^{\circ} \mathrm{C} .{ }^{*}$ Significantly different from control $(P<0.05)$ at that indicated ripening time point. Values are means of 2 replicates and error bars represent $\mathrm{SD}$. HHP = high hydrostatic pressure.

ripening, age-related changes (e.g., proteolysis) had a greater influence on rheological properties during the rest of the ripening period.

\section{Textural Properties}

An increase in HHP decreased cheese hardness (Table 2; Figure 6). Significant prediction models were obtained for TPA hardness (obtained from 20\% compression of cheese cylinders) during ripening. Pressure was the only significant term, and it negatively affected hardness values. We did not observe any significant difference $(P>0.05)$ between the control and cheeses treated at pressures $\leq 100 \mathrm{MPa}$. O'Reilly et al. (2000) reported that Cheddar cheeses became softer after HHP application of $50 \mathrm{MPa}$, but their holding times (3 d) were much longer than our study. Cheeses treated with pressures $\geq 225 \mathrm{MPa}$ remained softer than the control cheese during the entire ripening period (Figure 6). Uniaxial compression (obtained from $80 \%$ compression of cheese) profiles are shown in Figure 7. Application of HHP significantly increased the strain to fracture (Figure 1c; Table 2), indicating that these cheeses exhibited fracture at higher strains or did not fracture at all (Figure 7d). Similar observations were reported by Messens et al. (2000), who found that treatment of Gouda cheese at 225 and $400 \mathrm{MPa}$ resulted in cheese that exhibited lower firmness and no visible fracture. Johnston et al. (2002) observed softening in half-fat (15\% fat) Cheddar cheese with the application of HHP 100 to $500 \mathrm{MPa}$ for $2 \mathrm{~h}$. They attributed the HHPinduced reduction in firmness to a change in the state of water and a decrease in serum filled pores in the protein network. 


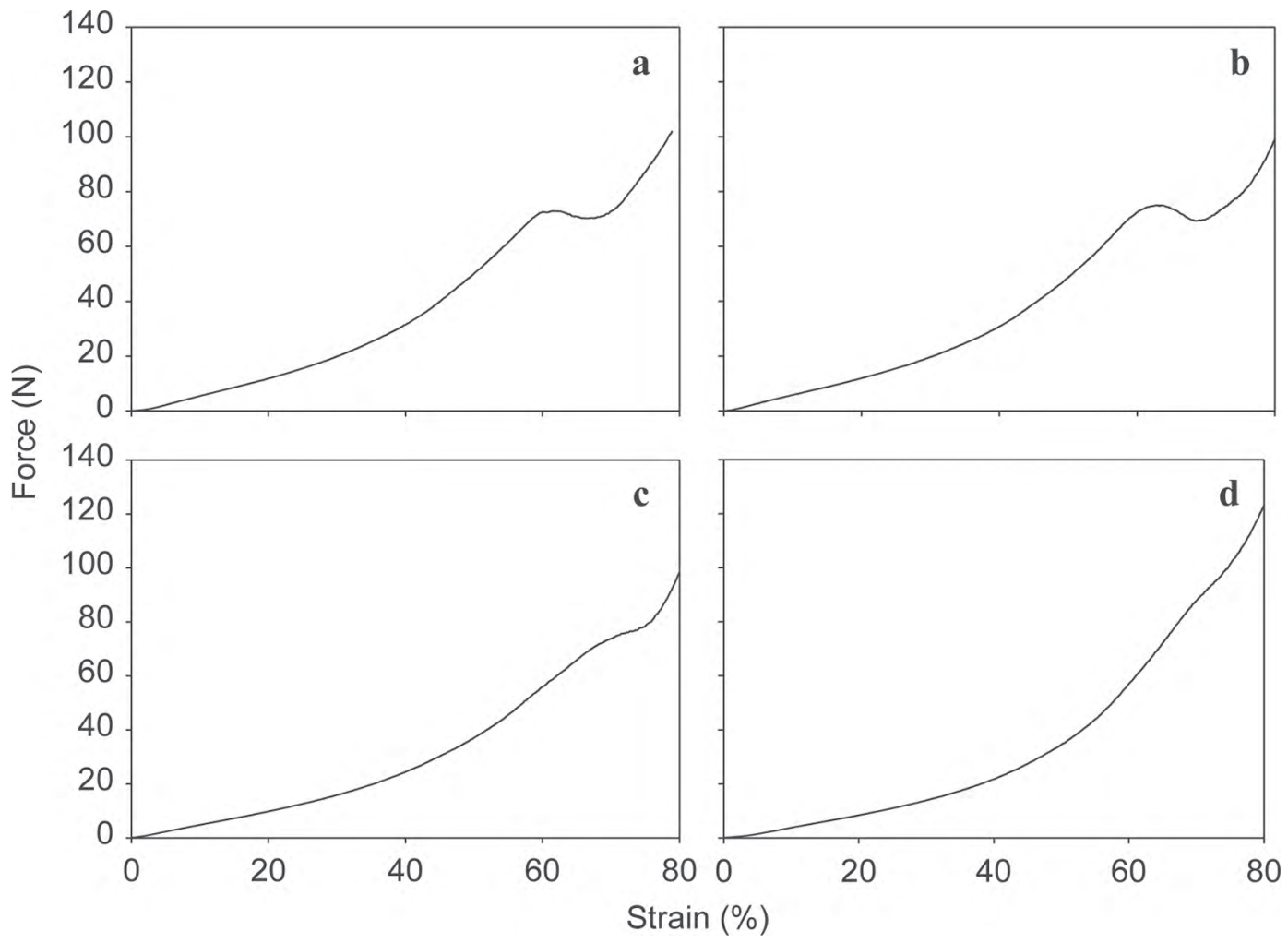

Figure 7. Uniaxial compression (compression by 80\%) curves for control (panel a), cheeses treated for 11 min at $48 \mathrm{MPa}$ (panel b), $11 \mathrm{~min}$ at $225 \mathrm{MPa}$ (a) (panel c), or $11 \mathrm{~min}$ at $402 \mathrm{MPa}$ (panel d). Reduced-fat Cheddar cheeses were tested at 2 wk of age.

\section{Fluorescence Microscopy}

Confocal laser scanning microscopy images demonstrated that large fat droplets finely dispersed into the cheese matrix with HHP treatment (Figure 8). Large fat droplets became less visible or less distinct with an increase in pressure. The lowest pressure application (48 $\mathrm{MPa}$ for $11 \mathrm{~min}$ ) had smaller fat droplets (Figure 8b) compared with the control (Figure 8a). Fat droplets were hardly visible at medium (225 $\mathrm{MPa}$ for $11 \mathrm{~min}$; Figure $8 \mathrm{c}$ ) or the highest pressure applications (402 MPa for 11 min; Figure 8d). The HHP treatment could have disrupted small fat droplets and dispersed the fat throughout the protein matrix; thereby, individual large fat droplets became less visible with an increase in pressure. O'Reilly et al. (2000) did not observe gross structural changes in Cheddar cheese by using confocal laser scanning microscopy with the application of 50 MPa for 70 h. Johnston and Darcy (2000) reported that fat globules and water channels in the protein matrix of young Mozzarella cheese almost disappeared with HHP application of $200 \mathrm{MPa}$ for $60 \mathrm{~min}$. Other researchers also reported that pressures $\geq 350 \mathrm{MPa}$ to Mozzarella cheese resulted in a more continuous and homogeneous protein matrix and reduced the size of fat-serum channels (O'Reilly et al., 2002a; Sheehan et al., 2005).

\section{Proteolysis and Informal Sensory Evaluation}

We did not observe any significant $(P>0.05)$ difference in water-soluble N (Figure 9a) or TCA-soluble $\mathrm{N}$ (Figure 9b) levels between HHP-treated cheeses and control cheese during the 6 mo of ripening. O'Reilly et al. (2000) and Yokohama et al. (1992) reported an increased proteolysis rate in Cheddar cheese with the application of $50 \mathrm{MPa}$ for $3 \mathrm{~d}$. However, both of these groups applied significantly longer holding times $(3 \mathrm{~d})$ compared with our study. O'Reilly et al. (2003) studied the effect of various pressures (70-400 MPa) and holding times $(3-81 \mathrm{~h})$ on Cheddar cheese. They reported that the application of pressures $<150 \mathrm{MPa}$ resulted in the highest levels of $\mathrm{pH} 4.6$-soluble $\mathrm{N}$ and long $(50-70 \mathrm{~h})$ holding times further increased $\mathrm{pH}$ 4.6-soluble $\mathrm{N}$ levels. However, they did not explain why longer holding times increased proteolysis rates. Messens et al. (1999) did not observe changes in the proteolysis rates in Gouda cheese compared with the untreated control when applying similar pressures and holding times (50-400 MPa, 20-100 min) as were performed in our study.

Informal sensory grading was conducted by 4 expert cheese graders, who indicated that HHP treatment altered the sensory properties of cheese. Several conditions (100 MPa for 5 and $17 \mathrm{~min}, 225 \mathrm{MPa}$ for $2.5 \mathrm{~min}$, 

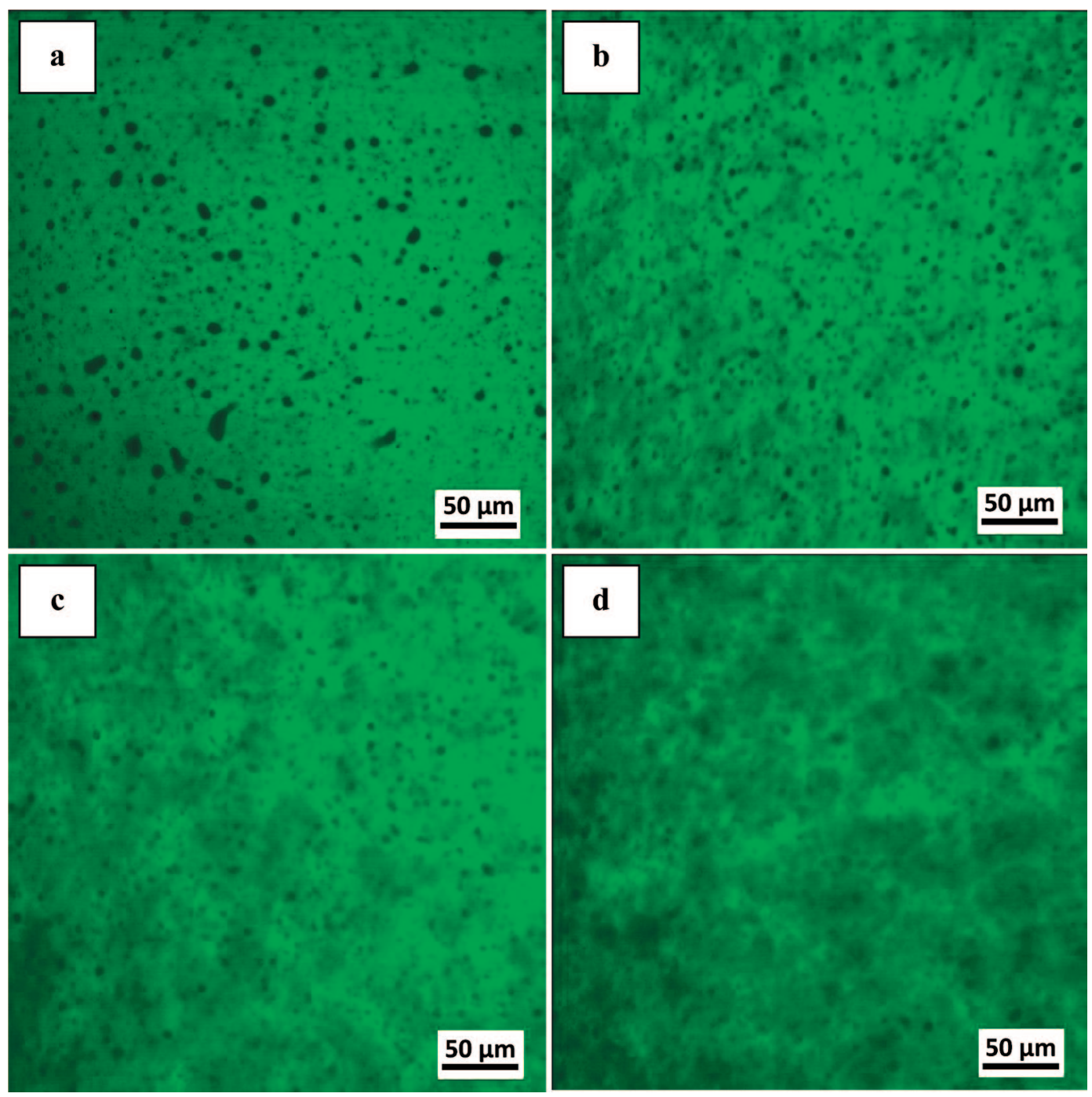

Figure 8. Fluorescence micrographs showing fat droplets as dark areas against a light (green) background (protein) for control (a), or cheeses treated for $11 \mathrm{~min}$ at $48 \mathrm{MPa}$ (b), $11 \mathrm{~min}$ at $225 \mathrm{MPa}(\mathrm{a})$ (c), or $11 \mathrm{~min}$ at $402 \mathrm{MPa}$ (d). Reduced-fat Cheddar cheese samples were at 3 wk of age. Color version available in the online PDF.

and $350 \mathrm{MPa}$ for $5 \mathrm{~min}$ ) applied to cheeses received promising sensory comments. An increase in pressure up to $350 \mathrm{MPa}$ increased the buttery and sweet notes up until 3 mo of ripening. Several mechanisms could be responsible for the possible changes in the sensory characteristics of experimental cheeses: more dispersed state of fat, impaired acid development, and greater release of intracellular enzymes into the protein matrix. The higher $\mathrm{pH}$ and residual lactose levels of HHP-treated cheeses could have contributed to the sweet notes.

\section{CONCLUSIONS}

Application of HHP significantly affected the texture and microflora of reduced-fat Cheddar cheese. In gen- eral, pressure exhibited greater effect on the textural and microbiological attributes compared with holding time. We did not observe any significant difference in proteolysis rates between HHP-treated cheeses and control cheese at any time of ripening. Pressure applications $\geq 225 \mathrm{MPa}$ resulted in softer cheese texture and increased melting; thus, high firmness and lower melting characteristics of reduced-fat cheeses could be improved by HHP treatment. High pressure did not alter the levels of INSOL Ca phosphate; it is still possible that some INSOL Ca phosphate crosslinks between proteins may have solubilized during the HHP application but the overall levels of INSOL Ca phosphate in cheeses were similar after pressure release. Pressure processing resulted in smaller fat droplets and a more continuous 


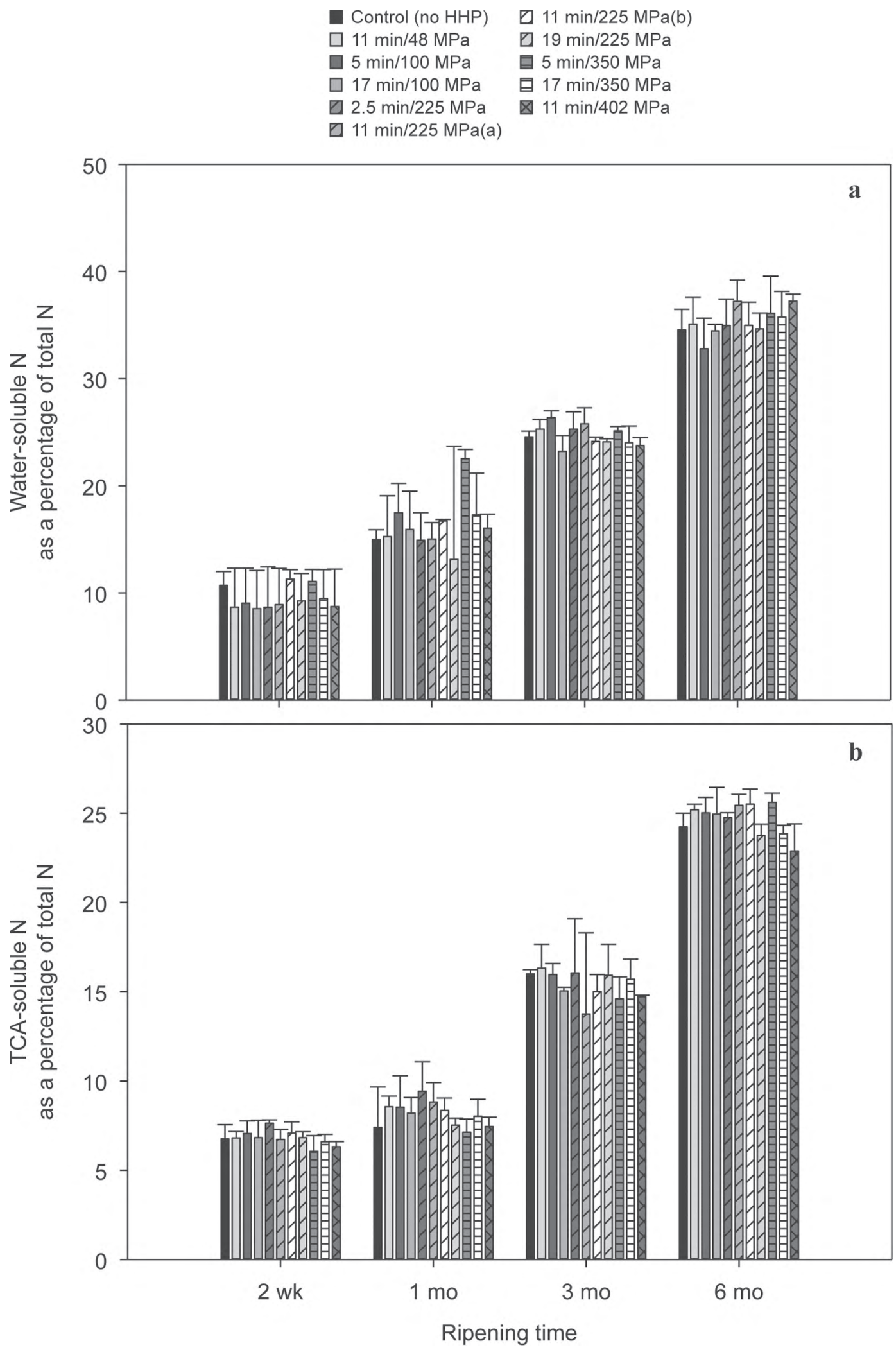

Figure 9. Water-soluble N (a) and 12\% TCA-soluble N (b) levels, expressed as a percentage of total N for reduced-fat Cheddar cheeses for control, or cheeses treated for $11 \mathrm{~min}$ at $48 \mathrm{MPa}, 5 \mathrm{~min}$ at $100 \mathrm{MPa}, 17 \mathrm{~min}$ at $100 \mathrm{MPa}, 2.5 \mathrm{~min}$ at $225 \mathrm{MPa}, 11 \mathrm{~min}$ at $225 \mathrm{MPa}(\mathrm{a}), 11 \mathrm{~min}$ at $225 \mathrm{MPa}(\mathrm{b}), 19 \mathrm{~min}$ at $225 \mathrm{MPa}, 5 \mathrm{~min}$ at $350 \mathrm{MPa}, 17 \mathrm{~min}$ at $350 \mathrm{MPa}$, or $11 \mathrm{~min}$ at $402 \mathrm{MPa}$ at 2 wk and 1, 3, and $6 \mathrm{mo}$ of ripening at $7^{\circ} \mathrm{C}$. Values are means of 2 replicates and error bars represent SD. HHP $=$ high hydrostatic pressure. 
protein network. Disruptions to protein-protein interactions (e.g., hydrophobic interactions), altered proteinwater interactions (protein hydration), or physical disruption to the matrix were probably responsible for the altered cheese texture and rheological properties. High hydrostatic pressure appears to be promising to improve texture and flavor of reduced-fat cheese.

\section{REFERENCES}

AOAC International. 2000. Official Methods of Analysis. 17th ed. AOAC International, Arlington, VA.

Black, E. P., C. M. Stewart, and D. G. Hoover. 2011. Microbiological aspects of high pressure food processing. Pages 51-71 in Nonthermal Processing Technologies for Food. H. Q. Zhang, G. V. Barbosa-Cánovas, V. M. Balasubramanian, C. P. Dunne, D. F. Farkas, and J. T. C. Yuan, ed. Wiley-Blackwell, Oxford, UK.

Boehringer Mannheim. 1997. UV method for the determination of lactose and D-galactose in food-stuffs and other materials. R-Biopharm test kit catalog \# 10176303 035. Boehringer Mannheim, Mannheim, Germany.

Broadbent, J. R., K. Houck, M. E. Johnson, and C. J. Oberg. 2003. Influence of adjunct use and cheese microenvironment on nonstarter bacteria in reduced-fat Cheddar-type cheese. J. Dairy Sci. 86:2773-2782.

Bryant, A., Z. Ustunol, and J. Steffe. 1995. Texture of Cheddar cheese as influenced by fat reduction. J. Food Sci. 60:1216-1219.

Carunchia Whetstine, M. E., M. A. Drake, B. K. Nelson, and D. M. Barbano. 2006. Flavor profiles of full-fat and reduced-fat cheese and cheese fat made from aged Cheddar with the fat removed using a novel process. J. Dairy Sci. 89:505-517.

Casal, V., and R. Gómez. 1999. Effect of high pressure on the viability and enzymatic activity of mesophilic lactic acid bacteria isolated from caprine cheese. J. Dairy Sci. 82:1092-1098.

Desobry-Banon, S., F. Richard, and J. Hardy. 1994. Study of acid and rennet coagulation of high pressurized milk. J. Dairy Sci. 77:3267-3274.

Green, W. C., and K. K. Park. 1980. Comparison of AOAC, microwave and vacuum oven methods for determining total solids in milk. J. Food Prot. 43:782-783.

Hassan, A., M. E. Johnson, and J. A. Lucey. 2004. Changes in the proportions of soluble and insoluble calcium during the ripening of Cheddar cheese. J. Dairy Sci. 87:854-862.

Johnson, M. E., and N. F. Olson. 1985. A comparison of available methods for determining salt levels in cheese. J. Dairy Sci. 68:1020-1024.

Johnston, D. E., and P. C. Darcy. 2000. The effects of high pressure treatment on immature Mozzarella cheese. Milchwissenschaft 55:617-620.

Johnston, D. E., M. O'Hagan, and D. W. Balmer. 2002. Effects of high pressure treatments on the textural and cooking performance of half-fat Cheddar cheese. Milchwissenschaft 57:198-201.

Juan, B., V. Ferragut, M. Buffa, B. Guamis, and A. J. Trujillo. 2007. Effects of high pressure on proteolytic enzymes in cheese: Relationship with the proteolysis of ewe milk cheese. J. Dairy Sci. 90:2113-2125.

Kuchroo, C. N., and P. F. Fox. 1982. Soluble nitrogen in Cheddar cheese: Comparison of extraction procedures. Milchwissenschaft 37:331-335.

Law, A. J. R., J. Leaver, X. Felipe, V. Ferragut, R. Pla, and B. Guamis. 1998. Comparison of the effects of high pressure and thermal treatments on the casein micelles in goat's milk. J. Agric. Food Chem. 46:2523-2530.

Law, B. A. 2001. Controlled and accelerated cheese ripening: The research base for new technologies. Int. Dairy J. 11:383-398.

Lee, M. R., M. E. Johnson, and J. A. Lucey. 2005. Impact of modifications in acid development on the insoluble calcium content and rheological properties of Cheddar cheese. J. Dairy Sci. 88:37983809.

Lucey, J. A., B. Hauth, C. Gorry, and P. F. Fox. 1993. The acid-base buffering properties of milk. Milchwissenschaft 48:268-272.

Lucey, J. A., M. E. Johnson, and D. S. Horne. 2003. Perspectives on the basis of the rheology and texture properties of cheese. J. Dairy Sci. 86:2725-2743.

Malone, A. S., T. H. Shellhammer, and P. D. Courtney. 2002. Effects of high pressure on the viability, morphology, lysis, and cell wall hydrolase activity of Lactococcus lactis ssp. cremoris. Appl. Environ. Microbiol. 68:4357-4363.

Malone, A. S., C. Wick, T. H. Shellhammer, and P. D. Courtney. 2003. High pressure effects on proteolytic and glycolytic enzymes involved in cheese manufacturing. J. Dairy Sci. 86:1139-1146.

Marshall, R. T. 1992. Standard Methods for the Examination of Dairy Products. 16th ed. American Public Health Association, Washington, DC

Martínez-Rodríguez, Y., C. Acosta-Muñiz, G. I. Olivas, J. GuerreroBeltrán, D. Rodrigo-Aliaga, and D. R. Sepúlveda. 2012. High hydrostatic pressure processing of cheese. Compr. Rev. Food Sci. Food Safety 11:399-416.

McSweeney, P. L. H., and M. J. Sousa. 2000. Biochemical pathways for the production of flavour compounds in cheeses during ripening: A review. Lait 80:293-324.

Messens, W., K. Dewettinck, J. Van Camp, and A. Huyghebaert. 1998. High pressure brining of Gouda cheese and its effect on the cheese serum. Lebenson. Wiss. Technol. 31:552-558.

Messens, W., J. Estepar-Garcia, K. Dewettinck, and A. Huyghebaert. 1999. Proteolysis of high-pressure-treated Gouda cheese. Int. Dairy J. 9:775-782.

Messens, W., J. Van Camp, and A. Huyghebaert. 1997. The use of high pressure to modify the functionality of food proteins. Trends Food Sci. Technol. 8:107-112.

Messens, W., D. Van de Walle, J. Arevalo, K. Dewettinck, and A. Huyghebaert. 2000. Rheological properties of high-pressure-treated Gouda cheese. Int. Dairy J. 10:359-367.

Montgomery, D. C. 2001. Design and Analysis of Experiments. 5th ed. John Wiley \& Sons, New York, NY.

Moschopoulou, E., T. Anisa, G. Katsaros, P. Taoukis, and G. Moatsou. 2010. Application of high-pressure treatment on ovine brined cheese: Effect on composition and microflora throughout ripening. Innov. Food Sci. Emerg. Technol. 11:543-550.

Mullen, K., and D. M. Ennis. 1979. Rotatable designs in product development. Food Technol. 33:74-75, 78-80.

Muthukumarappan, K., Y.-C. Wang, and S. Gunasekaran. 1999. Estimating softening point of cheeses. J. Dairy Sci. 82:2280-2286.

O'Reilly, C. E., A. L. Kelly, J. C. Oliveira, P. M. Murphy, M. A. E. Auty, and T. P. Beresford. 2003. Effect of varying high-pressure treatment conditions on acceleration of ripening of Cheddar cheese. Innov. Food Sci. Emerg. Technol. 4:277-284.

O'Reilly, C. E., P. M. Murphy, A. L. Kelly, T. P. Guinee, M. A. E. Auty, and T. P. Beresford. 2002a. The effect of high pressure treatment on the functional and rheological properties of Mozzarella cheese. Innov. Food Sci. Emerg. Technol. 3:3-9.

O'Reilly, C. E., P. M. O'Connor, P. M. Murphy, A. L. Kelly, and T. P. Beresford. 2000. The effect of exposure to pressure of $50 \mathrm{MPa}$ on Cheddar cheese ripening. Innov. Food Sci. Emerg. Technol. 1:109-117.

O'Reilly, C. E., P. M. O'Connor, P. M. Murphy, A. L. Kelly, and T. P. Beresford. 2002b. Effects of high-pressure treatment on viability and autolysis of starter bacteria and proteolysis in Cheddar cheese. Int. Dairy J. 12:915-922.

Park, Y. W. 2000. Comparison of mineral and cholesterol composition of different commercial goat milk products manufactured in USA. Small Rumin. Res. 37:115-124.

Reps, A., P. Kolakowski, and F. Dajnowiec. 1998. The effect of high pressure on microorganisms and enzymes of ripening cheeses. Pages 265-270 in High Pressure Food Science. Bioscience and Chemistry. N. S. Isaacs, ed. R. Soc. Chem., Cambridge, UK. 
Rynne, N. M., T. P. Beresford, T. P. Guinee, E. Sheehan, C. M. Delahunty, and A. L. Kelly. 2008. Effect of high-pressure treatment of 1 day-old full-fat Cheddar cheese on subsequent quality and ripening. Innov. Food Sci. Emerg. Technol. 9:429-440.

Saldo, J., A. Fernández, E. Sendra, P. Butz, B. Tauscher, and B. Guamis. 2003. High pressure treatment decelerates the lipolysis in a caprine cheese. Food Res. Int. 36:1061-1068.

Saldo, J., P. L. H. McSweeney, E. Sendra, A. L. Kelly, and B. Guamis. 2000. Changes in curd acidification caused by high pressure treatment. Ir. J. Agric. Food Res. 39:169-173.

Saldo, J., P. L. H. McSweeney, E. Sendra, A. L. Kelly, and B. Guamis. 2002. Proteolysis in caprine milk cheese treated by high pressure to accelerate cheese ripening. Int. Dairy J. 12:35-44.

Schrader, K., W. Buchheim, and C. V. Morr. 1997. High pressure effects on the colloidal calcium phosphate and the structural integrity of micellar casein. Nahrung 41:133-138.

Severn, D. J., M. E. Johnson, and N. F. Olson. 1986. Determination of lactic acid in Cheddar cheese and calcium lactate crystals. J. Dairy Sci. 69:2027-2030.

Sheehan, J. J., T. Huppertz, G. M. Hayes, A. L. Kelly, T. P. Beresford and T. P. Guinee. 2005. High-pressure treatment of reduced-fat
Mozzarella cheese: Effects on functional and rheological properties. Innov. Food Sci. Emerg. Technol. 6:73-81.

Sousa, M. J., Y. Ardö, and P. L. H. McSweeney. 2001. Advances in the study of proteolysis during cheese ripening. Int. Dairy J. 11:327-345.

Sutheerawattananonda, M., R. G. Fulcher, F. B. Martin, and E. D. Bastian. 1997. Fluorescence image analysis of process cheese manufactured with trisodium citrate and sodium chloride. J. Dairy Sci. 80:620-627.

Wehr, H. M., and J. F. Franks. 2004. Standard methods for the examination of dairy products. 17th ed. American Public Health Association, Washington DC

Wick, C., U. Nienaber, O. Anggraeni, T. H. Shellhammer, and P. D. Courtney. 2004. Texture, proteolysis and viable lactic acid bacteria in commercial Cheddar cheeses treated with high pressure. J. Dairy Res. 71:107-115.

Yokohama, H., N. Sawamura, and N. Motobayashi, inventors. 1992. Method for accelerating cheese ripening. Fuji Oil Co. Ltd., assignee. European Patent application EP, 469 857(0) A1. 